\title{
Urgency of Character Education Based on Multiculturalism
}

\author{
Ahsani Taqwiem \\ Department of Indonesian Language and Literature Education \\ Faculty of Teaching and Education \\ Universitas Lambung Mangkurat \\ Banjarmasin, Indonesia \\ ahsanitaqwiem@unlam.ac.id
}

\begin{abstract}
In the last few days we have seen many actions of certain groups in society who want to undermine the harmony of Indonesian nation. Religious and racial issues are sensitive issues that can lead to disintegration. The solution to avoid disintegration is to strengthen unity. Strong unity comes in a long process. One process that can be conducted is through education. Education that can produce unity in Indonesia is an education characterized by the principle of multiculturalism. Multicultural education is actually education mandated by the National Education System. The law in Indonesia explains that all forms of education residing in the territory of Indonesia should pay attention to the value of multiculturalism. Multiculturalism is understood differently by different countries. Multicultural education first emerged with the aim of calling attention to civil rights. The main purpose of the movement is to counter discriminatory practices against minority groups. Indonesia has a different history and culture certainly cannot directly apply the western version of multiculturalism. Multiculturalism must be understood as the foundation in building the life of nation and state. The development of character education based on multiculturalism in Indonesia must be in line with the principles formulated by national education ministry and in accordance with heterogeneous Indonesian society.
\end{abstract}

Keywords-education; character; multiculturalism

\section{INTRODUCTION}

The Indonesian people set Bhineka Tunggal Ika as national motto. This is expected to illustrate the spirit of Indonesian unity. Different ethnic, religious, racial, and customs are not obstacle to form a strong and powerful nation. Unity does not grow without the process. One of the processes that can be deployed is through education.

Education that produces unity is an education characterized by the principle of multiculturalism. The ideal Indonesian human character who values differences is the solution to prevent conflict. In the last few days we have seen many actions from certain groups in society that want to undermine the harmony of the nation. Religious and racial issues become sensitive issues that could trigger the breakup of unity. These events made the spirit of ke-Bhinneka-an again questioned.

Multicultural education is actually the mandate of Law Number 20 of 2003 on the National Education System. Article
3 [1] states that "National education develops the ability and form the character and civilization of a dignified nation in order to educate the nation's life, aiming at the development of the potential of learners to be a devout believer, noble, healthy, knowledgeable, capable, creative, independent, democratic and responsible citizen ".

Article 3 [1] generally requires national education to produce intelligent and humanist Indonesians. If this can be achieved, the potential for disunity will be easily avoided. Therefore, it is necessary to study this matter continuously so that understanding of character education and respecting differences can be implemented well in every level of education.

Article 4 [1] of Law Number 20 Year 2003 states that "Education is conducted in a democratic, fair and nondiscriminatory manner by respecting human rights, religious values, cultural values, and national pluralism." It is clear that all forms of education in the territory of Indonesia uphold values of multiculturalism. Of course this part of regulation is a reflection that the differences within the Indonesian nation are an inevitable necessity. Our task is certainly not at the stage of affirming differences, but rather seeking equality for the sake of the integrity of the nation and state.

Character becomes a bustling topic and one of the solution options for various nation problems. Kemendikbud (culture and national education ministry) in 2011 formulated 18 types of values of character typical of Indonesia, which are being religious, honest, tolerant, discipline, hard-working, creative, independent, democratic, curious, having spirit of nationality, having love of the homeland, appreciating achievement, being friendly or communicative, loving peace, loving to read, caring about the environment, having social care, and responsibility.

Character is the set of values that leads to a system, which underlies the thoughts, attitudes, and behaviors displayed [2]. Character education discourse appears because of the many indications that this nation, especially the successor generation has entered the stage of morality crisis. Free intercourse, child abuse, theft, drug abuse, pornography, and the culture of corruption have become problems that until now have not been solved. The world of education is forced to transform because the results of the education system which have only 
focused on the cognitive domain were less effective in an effort to produce a generation who has intellectual and moral intelligence.

When talking about character, we talk about substance that cannot be changed in a short time. Particularly, the teaching is pinned on the educational process that requires the process to arrive at the expected results. This important step seems to have been acted upon by the government because in the near future the Presidential Decree on the Improvement of Character Education (PPK) will be determined.

If the Presidential Decree on the Improvement of Character Education (PPK) is realized, this is an indication that the government has also been working hard to find solutions to the moral crisis and potential disintegration of the nation. Indonesia's diversity is an extraordinary power if it is well managed. Indonesia will have strong and solid character. The character will be the foundation of this nation and developed into a great nation in the future.

\section{LITERATURE REVIEW}

Multicultural education is not native education of Indonesia. This education is a typical style of Western education. Canada is a country where multiculturalism emerged for the first time around the 70s. Subsequently, Canada steps were followed by other countries such as Australia, United States, and England.

Multiculturalism is understood differently by individual countries. This happens because of differences in historical and cultural aspects between countries. Indonesia which has a different history and culture, cannot use western multiculturalism directly. There must be an adjustment so that the value of multiculturalism can be accepted by society. Some other terms that refer to multicultural education are intercultural education, inter-ethnic education, cross-cultural education, multi-education education, and cross-cultural education.

Multicultural education first emerged with the aim of fighting for civil rights. The main purpose of the movement is to counter discriminatory practices against minority groups. Multiculturalism in practice enters various social interactions in human life. This movement also has an impact on education. The educational aspect is needed to produce educational programs with regard to aspects of ethnic and cultural diversity. As an ideology, multiculturalism must be fought for because its presence is essential as a foundation for the establishment of justice in various sectors of life.

The root of multiculturalism is culture. Cultural understanding according to experts is very diverse, but in this context culture is seen in the perspective of its function as a guide for human life. In the context of cultural perspective, multiculturalism is an ideology that can be a tool or vehicle to improve humanity and humanity [3].

Multicultural education is about the culture of heterogeneity. This definition is broader than has previously defined. Regardless the same cultural position as stated in the aforementioned definition, cultural diversity should be learned with status itself as a learning object. In other words, men become mated heterogeneous cultural lessons to consider curriculum developers [4]. Multiculturalism must be understood as a foundation in building the life of the nation and the state, especially for countries that have cultural diversity like Indonesia. Through this multicultural education, it is expected that we can achieve a peaceful society living order, harmonious, and uphold the values of humanity as aspired to the constitution.

Multicultural education is a concept, idea or philosophy as a set of beliefs and explanations that recognize and value the importance of cultural and ethnic diversity in shaping lifestyles, social experiences, personal identities, individual opportunities, groups and countries [5].

\section{Result AND Discussion}

Implementation of character education that is based on multicultural cannot be equated with what other countries do because of different histories and cultures, in addition to the approach in the education world of each country which is very different. Therefore, multiculturalism in Indonesia should also be achieved with character education that grows and develops according to diverse Indonesian society.

The development of character education in Indonesia has a reference published by Kemdiknas [6] as a formula of principles of character education. These principles include:

1) promoting basic ethical values as the basis of character;

2) identifying character comprehensively to include thoughts, feelings, and behaviors;

3) using a sharp, proactive and effective approach to building character;

4) creating a caring school community;

5) providing an opportunity for learners to show good behavior;

6) having coverage of a meaningful and challenging curriculum that values all learners, builds their character, and helps them to succeed;

7) seeking the growth of self-motivation in the learners;

8) functioning all school staff as a moral community that shares responsibility for character education and is faithful to the same basic values;

9) having the division of moral leadership and broad support in building character education initiatives;

10) functioning families and community members as partners in building character;

11) evaluating school character, function of school staff as character teachers, and manifestation of positive character in the learner's life.

In relation to the development of character education, Burnett developed four values that are appreciation of the reality of cultural plurality in society, recognition of human dignity and human rights, the development of the 
responsibility of the world community, and the development of human responsibility towards the earth [7].

These values can be adopted in the basic principles of the development of a multicultural education-based learning model. First, multicultural education should start from each individual. Identity as an Indonesian citizen must be well implanted. If this is done, it is expected that learners do not regard diversity as a deficiency, but rather make it an advantage. Understanding identity means to be proud of oneself, with the pride it possesses and keeps getting stronger. This will make the disintegration potential of the nation easily overcomed.

Second, multicultural education should be developed, so learners do not develop ethnocentric attitudes. Proud attitude with culture or tribe is actually good, but if it is excessive, it will lead to the best feelings and demeaning others. This is dangerous to reach the nation's ideals. The realization that we live in a broad social environment must be given. This will foster a different attitude of intergroup tolerance. Multicultural education aims to build non-egocentric awareness.

Third, multicultural education is developed in an integrative way. It should be remembered that all aspects of education should be developed with respect to diversity. The effort of development is not just partial and not thorough. The curriculum of multicultural education should be integrated into all subjects, such as language, social science, science, physical education, arts, and other subjects.

Fourth, multicultural education must produce a change of attitude through habituation. Learning theory is good but it should not be finished without entering on the implementation of the studied theory. Implementation of the theory is lack from all of us. Learning practices are designed in a learning community atmosphere that values diversity, tolerance, and shared goals of loving nation and country. Learning should be process-oriented, such as role playing, simulation, discussion, cooperative learning, and participatory learning.

Fifth, multicultural education should include the social and historical realities of religion, ethnicity and ethnicity. Contextualization of multicultural education should be local, national, and global. Pride has the value of local wisdom which must be grown. Awareness of nationalism must be a common goal of national education. Awareness as a global citizen by upholding the values of international peace should be developed. Such contextualization has an important meaning to foster respect, tolerance, and respect for diversity within the social, community, and world social circles [8].

\section{CONCLUSION}

Multicultural-based education is an education mandated by the Law. Education in Indonesia is succinctly changing because the outcome of the education system is only focused on the cognitive domain of producing a smart but intolerant generation. The morality critique that occurs can be overcomed by the process of positive character learning.

Characters cannot be changed quickly. Moreover, character teaching is embedded in an educational process that requires a process to arrive at the expected outcome. This important step seems to have begun with the news of the upcoming Perpres (Presidential Regulation) on the Strengthening of Character Education (Penguatan Pendidikan Karakter/ $P P K$ ) in the near future.

Multiculturalism in Indonesia should also be achieved with character education that grows and evolves according to diverse Indonesian society. Through this multiculturalism education is expected to achieve peaceful, harmonious, and uplifting human values as desired by the basic law.

\section{REFERENCES}

[1] Departemen Pendidikan Nasional, Undang-Undang Nomor 20 Tahun 2003, Tentang Sistem Pendidikan Nasional, Jakarta: Depdiknas, 2003.

[2] S.Philips, Refleksi Karakter Bangsa, Jakarta: Bumi Aksara, 2008

[3] P. Suparlan, "Menuju Masyarakat Indonesia yang Multikultural," Jurnal Antropologi Indonesia, pp. 1, July 16-21, 2002.

[4] R. Andersen and K. Cusher, "Multicultural and Intercultural Studies" in C. Marsh [ed.], Teaching Studies of Society and Environment, Sydney: Prentice-Hall, 1994, pp. 320.

[5] HAR Tilaar, Mutikulturalisme: Tantangan-tantangan Global Masa Depan dalam Transpormasi Pendidikan Nasional, Jakarta: Grasindo, 2004, pp. 181.

[6] Kementerian Pendidikan Nasional, Panduan Pendidikan Karakter, Jakarta: Kemdiknas, 2010.

[7] N. Naim and A. Sauqi, Pendidikan Multikultural: Konsep dan Aplikasi, Jokjakarta: Ar-Ruzz Media, 2008, pp. 213.

[8] Sariban, Pendidikan Multikultural Pembentuk Karakter Ke-Indonesiaan, http://www.gurupintar.ut.ac.id/index.php/content/materi-pengayaanpembelajaran-dalam-artikel/pendidikan-multikultural-pembentukkarakter-keindonesiaan, 2017. 